\author{
NEUROENDOCRINE FACTORS IN AFFECTIVE DISORDERS
}

M. ANSSEAU*, W. PITCHOT*, P. PAPART*, A. GONZALEZ MORENO*, M. LEMBREGHTS* and J.J. LEGROS*

* Psychiatric Unit and ** Psychoneuroendocrinology Unit, University of Liège, C.H.U. du Sart Tilman (B35), B-4000 Liège, Belgium

Neuroendocrine strategy may provide an indirect index of central neurotransmission which is particularly interesting in the biological assessment of affective disorders. In this article, we will briefly review our work concerning the clinical usefulness of the growth hormone (GH) response to clonidine, a a2-noradrenergic agonist, and apomorphine, a dopaminergic agonist.

\title{
Diagnostic usefulness
}

The GH responses after clonidine and apomorphine challenges were compared in 2 matched samples of 15 major depressive and 15 minor depressive inpatients (2). Following clonidine, major depressives exhibited a significantly lower peak GH response than minor depressives: $4.0 \pm 6.8 \mathrm{ng} / \mathrm{ml}$ vs $11.7 \pm 7.5 \mathrm{ng} / \mathrm{ml}, \mathrm{p}<0.01$. Following apomorphine, major depressive patients also exhibited a significantly lower GH response than minor depressives : $5.3 \pm 3.8 \mathrm{ng} / \mathrm{ml}$ vs $20.4 \pm 12.7 \mathrm{ng} / \mathrm{ml}$, $\mathrm{p}<0.001$. In another study (1), we found similarly blunted GH responses to clonidine and apomorphine in 7 drug-free manic and 7 matched major depressive inpatients. Following clonidine, mean GH peaks (SD) were 3.2 $\pm 2.4 \mathrm{ng} / \mathrm{ml}$ in manics and $3.2 \pm 2.4 \mathrm{ng} / \mathrm{ml}$ in major depressives and following apomorphine respectively $10.5 \pm 7.4 \mathrm{ng} / \mathrm{ml}$ and $3.2 \pm 1.9 \mathrm{ng} / \mathrm{ml}$. Results of this study support the hypothesis that a2-receptor abnormalities represent a trait marker for affective disorder.

Clinical correlates

The relationship between GH response to clonidine or apomorphine and the Minnesota Multiphasic Personality Inventory (MMPI) was assessed in 20 major depressive inpatients $(5,6)$. GH response to clonidine was negatively correlated with the depression $(r=-0.52, p<0.02)$, the psychasthenia $(\mathrm{r}=-0.53, \mathrm{p}=0.01)$ as well as the social introversion $(\mathrm{r}=-0.44, \mathrm{p}=0.05)$ MMPI scale scores, and positively correlated with the hypomania $(\mathrm{r}=0.47, \mathrm{p}=0.04)$ scale scores. GH response to apomorphine was positively correlated with the social introversion ( $r=$ $0.56, \mathrm{p}=0.01)$ and the anxiety scale scores $(\mathrm{r}=0.45, \mathrm{p}=0.04)$. Therefore, the clonidine test seems to relate to the depressive/manic dimension whereas the apomorphine test seems more related to the dimension of social introversion and anxiety, in agreement with the dopaminergic hypothesis of schizophrenic disorders and with the role of dopaminergic hyperactivity in anxiety disorders.

The relationships between the life-events preceding hospitalization and abnormalities following clonidine and apomorphine challenges were assessed in 41 major depressive inpatients (3). Patients exhibiting a blunted GH response to clonidine $(n=28)$ did not exhibit significantly different rating of mean total negative impact of independent life-events as compared to patients with normal responses $(n=13): 11.43$ vs 12.27 . In contrast, a higher impact of life-events was noted in patients 
exhibiting blunted response to apomorphine $(n=28)$ as compared to patients with normal stimulation $(n=13): 13.20$ vs $8.29, p=0.01$. According to these findings, the clonidine test may represent a "traitmarker" of depressive vulnerability; in contrast, the apomorphine test seems to represent more a "state-marker" of depressive illness.

The relationship between clonidine and apomorphine challenges and suicidal behavior was assessed in 15 major depressive inpatients with a history of suicide attempts who were individually matched with 15 major depressive inpatients without history of suicidal behavior (7). Both mean GH peak responses were significantly lower in the group of suicide attempters than in the control group : after clonidine, $2.9 \pm 2.8 \mathrm{ng} / \mathrm{ml}$ vs $7.6 \pm 7.9 \mathrm{ng} / \mathrm{ml}, \mathrm{p}<0.05$ and after apomorphine, $6.4 \pm 4.9 \mathrm{ng} / \mathrm{ml}$ vs $17.1 \pm 10.3 \mathrm{ng} / \mathrm{ml}, \mathrm{p}<0.001$. Therefore, these results suggest that blunted GH responses to clonidine or apomorphine could be considered as a biological risk factor of suicidal behavior.

\section{Prediction of treatment response}

Blunted $\mathrm{GH}$ responses to clonidine or apomorphine might be arguments favoring catecholaminergic deficit and therefore orientate to "catecholaminergic" antidepressant. In contrast, a normal GH response to both challenges could reflect normal catecholaminergic neurotransmission and orientate to "serotonergic" antidepressants. Clonidine and apomorphine tests were performed in 62 major depressive inpatients who were then randomly assigned to treatment by either nomifensine, a catecholaminergic antidepressant, or zimeldine, a serotonergic antidepressant (4). Clinical outcome following the 3 weeks of therapy was assessed by means of the clinical global impressions. Among patients exhibiting a blunted $\mathrm{GH}$ response to clonidine, there was no difference in treatment outcome between the 15 patients treated with nomifensine and the 15 patients treated with zimeldine. In contrast, among the patients exhibiting a normal GH stimulation, the 11 patients treated with zimeldine responded significantly better than the 12 patients treated with nomifensine $(p=0.004)$. Among patients exhibiting blunted response to apomorphine, the 7 patients treated with nomifensine exhibited a much better treatment outcome as compared to the 8 patients treated with zimeldine $(p=0.0001)$. The opposite was true for patients who exhibited normal GH response: the 18 patients treated with zimeldine exhibited a significantly more favorable outcome than the 21 patients treated with nomifensine $(p=0.0001)$. Therefore, these findings support the clinical usefulness of clonidine and apomorphine challenges in the prediction of treatment response to selective antidepressants.

\section{$\underline{\text { References }}$}

1. Ansseau et al. (1987) : Psychiatry Res., 22:193-206.

2. Ansseau et al. (1988) : Br. J. Psychiatry, 153:65-71.

3. Ansseau et al. (1990) : In Psychiatry: A World Perspective, vol. 2, C. Stefanis, C.R. Soldatos, A.D. Rabavilas, eds., pp. 265-269. Excerpta Medica, Amsterdam.

4. Ansseau et al. (1991) : In Biological Markers of Depression: State of the Art, M. Ansseau, R. von Frenckell, and G. Franck, eds., pp. 63-68. Excerpta Medica, Amsterdam.

5. Hansenne et al. (1992) : Eur. Psychiatry, in press.

6. Pitchot et al. (1991) : Neuropsychobiology, in press.

7. Pitchot et al. (1992) : Biol. Psychiatry, in press. 